\title{
Influence of crop management practices on bean foliage arthropods
}

\author{
J.L. Pereira ${ }^{1,2}$, M.C. Picanço1 ${ }^{1}$, E.J.G. Pereira ${ }^{1,3 *}$, A.A. Silva ${ }^{2}$, \\ A. Jakelaitis ${ }^{4}$, R.R. Pereira ${ }^{1}$ and V.M. Xavier ${ }^{1}$ \\ ${ }^{1}$ Departamento de Biologia Animal and ${ }^{2}$ Departamento de Fitotecnia, \\ Universidade Federal de Viçosa, MG, Viçosa, 36571-000, Brazil: \\ ${ }^{3}$ Departamento de Ciências Agrárias, Universidade Federal de Viçosa - \\ Campus Rio Paranaíba, Rio Paranaíba, MG, 38810-000, Brazil: ${ }^{4}$ Instituto \\ Federal de Educação, Ciência e Tecnologia Goiano, Campus de Urutaí, \\ GO 75790-000, Brazil
}

\begin{abstract}
Crop management practices can affect the population of phytophagous pest species and beneficial arthropods with consequences for integrated pest management. In this study, we determined the effect of no-tillage and crop residue management on the arthropod community associated with the canopy of common beans (Phaseolus vulgaris L.). Abundance and species composition of herbivorous, detritivorous, predaceous and parasitoid arthropods were recorded during the growing seasons of 2003 and 2004 in Coimbra County, Minas Gerais State, Brazil. Arthropod diversity and guild composition were similar among crop management systems, but their abundance was higher under no-tillage relative to conventional cultivation and where residues from the preceding crop were maintained in the field. Thirty-four arthropod species were recorded, and those most representative of the impact of the crop management practices were Hypogastrura springtails, Empoasca kraemeri and Circulifer leafhoppers, and Solenopsis ants. The infestation levels of major insect-pests, especially leafhoppers (Hemiptera: Cicadellidae), was on average seven-fold lower under no-tillage with retention of crop residues relative to the conventional system with removal of residues, whereas the abundance of predatory ants (Hymenoptera: Formicidae) and springtails (Collembola: Hypogastruridae) were, respectively, about seven- and 15-fold higher in that treatment. Importantly, a significant trophic interaction among crop residues, detritivores, predators and herbivores was observed. Plots managed with no-tillage and retention of crop residues had the highest bean yield, while those with conventional cultivation and removal of the crop residues yielded significantly less beans. This research shows that cropping systems that include zero tillage and crop residue retention can reduce infestation by foliar insect-pests and increase abundance of predators and detritivores, thus having direct consequences for insect pest management.
\end{abstract}

Keywords: no-tillage, residue management, Phaseolus vulgaris, Zea mays, abundance, Collembola, Solenopsis, leafhoppers, path analysis, trophic cascade

(Accepted 20 December 2009)

*Author for correspondence

Fax: (+55) (34) 3855-9000

E-mail: eliseu.pereira@ufv.br 


\section{Introduction}

Adoption of conservation tillage and direct sowing of crops have increased in recent decades, especially in tropical regions. No-tillage has several advantages over conventional cultivation, some of which are reduction of soil erosion and nutrient leaching, maintenance of thermal stability on the soil surface, conservation of water and reduction of production costs (Gebhardt et al., 1985). Changes in tillage, however, could induce shifts in the number and composition of the arthropod fauna, including both pests and beneficial organisms. Tillage, or lack of it, influences arthropods, primarily by mechanical disturbance, residue placement and effects on weed communities (Stinner \& House, 1990).

The common bean, Phaseolus vulgaris L., is an herbaceous annual plant grown worldwide for its edible bean, popular both dry and as a green bean and occupying the status of most consumed legume in the world (FAO, 2009). In addition to the socio-economic importance as protein source for humans and livestock, the crop also plays a key ecological role because of its symbiosis with nitrogen fixing bacteria. Despite that, bean plants are demanding in nutrients and have a superficial rooting system, requiring the use of conservation tillage and crop rotation to sustain stable yield (Vieira et al., 2006). In Brazil, the world biggest producer of common bean, about $85 \%$ of the 4 million ha planted is grown by small farmers although the crop is increasingly attracting investments of large farmers encouraged by market prices and changes in cultivation practices that minimize risks of yield losses (Vieira et al., 2006). Maize, one of the main crops in the world, is suitable for rotation with bean given their different rooting habits, complexes of pests and diseases, and accumulation of crop residues (Fornasieri, 1992; Díaz-Zorita et al., 2002; Vieira et al., 2006). In this system, the maize can be cultivated for production of grains, in which the crop residues are left on the soil, and for silage, in which the entire plant biomass is harvested for animal feed. The retention or removal of the maize plant residues could influence the abundance and composition of the arthropod community in the maize-bean agroecosystem (Stinner \& House, 1990), an effect which is generally attributed to a higher availability and quality of food and shelter to these organisms (House \& Stinner, 1983; Marasas et al., 2001).

The arthropod community associated with the canopy of bean plants comprises numerous species including herbivores, detritivores, predators and parasitoids. Fields of common beans are frequently subjected to heavy losses caused mainly by phytosuccivorous pests in Brazil, such as the green leafhopper and thrips, among others (Magalhães \& Carvalho, 1988; Marquini et al., 2002; Vieira et al., 2006). A variety of predator and parasitoid species help to suppress pest populations, but insecticide applications are frequently necessary and can significantly reduce the arthropod abundance (Marquini et al., 2002). Current research directions in integrated pest management emphasize tropic interactions among insect pests, natural enemies and other crop pests, such as weeds, leading to a recent rebirth in interest and research activities on cultural and biological controls (Andow, 1991; Norris \& Kogan, 2005; Shennan, 2008).

If crop management practices increase the organic detritus on the soil and enhance the density or activity of detritivorous arthropods, they may support the generalist predator community and open up more opportunities for top-down effects important to natural biological control of insects (Settle et al., 1996; Wise et al., 1999; Scheu, 2001). Both theory and practice suggest that generalist predators can be effective control agents, especially if favored by appropriate crop management (Afun et al., 1999; Landis et al., 2000; Symondson et al., 2002). A classic demonstration in irrigated Asian rice involved increasing the amount of organic matter leading to increases in detritivores, plankton-feeders and generalist predators (Settle et al., 1996). Fire ant species are abundant in a number of tropical agroecosystems (Way et al., 1998; Rossi \& Fowler, 2004), and their role in biological control is increasingly being recognized (Risch \& Carroll, 1982; Rossi \& Fowler, 2000; Stiles \& Jones, 2001; Way et al., 2002). These generalist predators may be favored by management practices that promote low levels of soil disturbance and increase habitat complexity (Landis et al., 2000; Symondson et al., 2002; Harvey \& Eubanks, 2004).

Effects of agricultural practices on arthropod assemblages are complex, reflecting the interaction of biological traits of particular species and the combination of agronomic treatments applied. The contrasting response of different arthropod species to conservation tillage systems has diverse consequences for pest management, leading some authors (e.g. Tonhasca, 1993; Carcamo et al., 1995) to suggest focusing only on more relevant species to improve the predictive capacity of impact studies in such systems. Considering the importance of the arthropods in the bean agroecosystem, impact studies of management systems that conserve crop productivity and promote agroecosystem sustainability are of great relevance. Such studies are scarce, especially in the common bean, a crop of great socio-economic and ecological importance in tropical regions. Therefore, this research was designed to study the separate and combined effects of contrasting soil management practices and the retention or removal of crop residues on the arthropod community of the canopy of $P$. vulgaris, trying to understand processes that have consequences for integrated pest management.

\section{Material and methods \\ Experimental fields}

This research was conducted at the University of Viçosa's experimental station $\left(20.85^{\circ} \mathrm{S}, 42.80^{\circ} \mathrm{W}, 720 \mathrm{~m}\right.$ ASL, in Coimbra County, State of Minas Gerais, Brazil) during the growing seasons of 2003 and 2004. The regional climate is humid subtropical (classified as Cwa by the Köppen system), and the soil type of the area resembles the Paleudult of the American Classification, which is nutrient poor with moderate depth and low water permeability (Resende et al., 1988; Soil Survey Staff, 1999). Five nearby 1-ha fields were utilized. Since 1998, half of each field has been managed using no-tillage and the other half using conventional cultivation, and maize for grain production has been sown in early November (wet season) and common beans in early June (dry season). To assess the effect of the residue management of the maize crop (i.e. mulching) on the arthropod assemblage associated with the bean plant canopy, the maize was harvested for silage in some plots and for grain in others. These treatments were chosen to represent situations when the crop residues are removed (maize for silage) or maintained in the area (maize for grain). Experimental plots within each field measured $28 \times 75 \mathrm{~m}^{2}$ 
containing 56 rows $0.45 \mathrm{~m}$ apart with 12 bean plants per linear meter. Each one of five fields (blocks) contained all four treatments (conventional cultivation and no-tillage, with and without removal of the maize crop residues).

Cultivation practices were utilized as commonly made in the region (Vieira et al., 2006) with mechanical control of weeds and no post-emergence use of herbicides. In the no-tillage system, weed desiccation was carried out ten days before sowing using the mixture glyphosate $+2,4-\mathrm{D}$ $\left(1440+670 \mathrm{gha}^{-1}\right)$. For the conventional cultivation, no desiccation was done and tillage was carried out two days before sowing by using one plowing with a disc plough, to a depth of $20-25 \mathrm{~cm}$, and two secondary tillage operations with a light disc harrow $(10-15 \mathrm{~cm})$ to obtain a uniform terrain and incorporate crop residues.

Black beans of the cultivar Meia Noite, which has indeterminate growth and a cycle of 90 days, were sowed on 6 June 2003 (1st year) and 1 June 2004 (2nd year). A 250$\mathrm{kg} \mathrm{ha}^{-1}$ mixture of $\mathrm{N}, \mathrm{P}_{2} \mathrm{O}_{5}$ and $\mathrm{K}_{2} \mathrm{O}$ (8-28-16) was utilized as fertilizer. Twenty-five days after emergence, a $60-\mathrm{g} \mathrm{ha}^{-1}$ dose of molybdenum was applied and so was a $4-\mathrm{kg} \mathrm{ha}^{-1}-\mathrm{N}$ dose (ammonium sulphate) in the beginning of the flowering period. Plants were irrigated weekly until 60 days after emergence by using a central pivot equipped with sprinklers spaced $12 \mathrm{~m}$, working at $450 \mathrm{kPa}$ pressure and applying $327 \mathrm{~m}^{3} \mathrm{~h}^{-1}$ water.

\section{Arthropod sampling and biomass measurements}

Arthropods were sampled from the plant canopy at 20, $28,35,43,56,70$ and 84 days after the emergence of seedlings in the first year and at 18, 23, 31, 37, 52, 67 and 73 days after emergence in the second year. In each experimental plot, the apical leaves of five plants were beaten against a white plastic tray $(35 \mathrm{~cm}$ long $\times 30 \mathrm{~cm}$ wide $\times 5 \mathrm{~cm}$ deep) according to a sampling plan developed by Moura et al. (2007). The arthropods collected were placed in vials containing $70 \%$ ethanol and later separated to morphospecies and sent to taxonomists for identification.

Assessment of weed biomass and maize crop residues was carried out one day before the first arthropod sampling date. In each experimental plot, maize crop residues were randomly collected in a $1-\mathrm{m}^{2}$ area, and so were weeds, by using two metal squares $\left(0.3 \times 0.3 \mathrm{~m}^{2}\right)$. The weeds present within the squares were collected and washed in water to eliminate soil residues. Both weeds and maize crop residues were dried in a ventilated oven at $75 \pm 5^{\circ} \mathrm{C}$ until reaching constant weight. Bean yield was determined by manually picking up the plants present in $5 \mathrm{~m}$ of the two central rows in each plot. Beans were harvested and dried in a ventilated oven at $50^{\circ} \mathrm{C}$ until reaching $13 \%$ moisture content. After drying, the plant material was weighted utilizing an electronic scale with precision of $0.01 \mathrm{~g}$. Values of biomass of weeds and crop residues were converted to $\mathrm{g} \mathrm{m}^{-2}$, as was the yield of beans to ton ha ${ }^{-1}$.

\section{Statistical analyses}

The weed biomass, crop residues and yield of beans were subjected to univariate analysis of variance (ANOVA), and the means were separated using Tukey's honestly significant difference (HSD) procedure with $P<0.05$. The impact of the treatments on the arthropod assemblage was determined by comparing arthropod richness and relative abundance of each species. Both the total number of species and that in each guild were subjected to ANOVA with $P<0.05$. The assumptions of normality and homogeneity of variances were tested before data were analysed (PROC UNIVARIATE PROC GPLOT: SAS Institute, 2001). Similar procedures were utilized for the following analyses, and transformation was not necessary.

The data on relative abundance in the two years were subjected to a selective process of species accounting for the maximum explained variance (PROC STEPDISC with STEPWISE selection: SAS Institute, 2001; Badji et al., 2004). The species were selected based on three coincident criteria: (i) mean frequency of capture above 10\%, (ii) significant $F$-value $(P<0.10)$ in the analysis of covariance with species as covariates and treatments as dependent variables, and (iii) significant partial canonical correlation $(P<0.10)$ (SAS Institute, 2001; Badji et al., 2004).

Data from the selected species were treated separately in the two years and subjected to a canonical variate analysis (CVA) to represent graphically the relative positions and orientations of the mean response of the arthropod community in each treatment (Kedwards et al., 1999). The significance of the separation was tested by pairwise comparison of the treatments by the approximated $F$ test $(P<0.05)$ using the Mahalanobis distance between the respective class mean canonical variates (PROC CANDISC: SAS Institute, 2001). Main species were those that canonical coefficients most contributed to treatment differences in the significant axes.

The relative abundance of the main species during the crop growing cycle was subjected to a repeated-measure analysis of variance using the ANOVA procedure from SAS with the PROFILE statement (Von Ende, 1993). Path analyses using PROC REG and PROC CALIS (Mitchell, 1993; SAS Institute, 2001) were additionally carried out to study the hypothesized interactions among herbivores, predators, detritivores, crop residues and weeds. The interactions between the variables were represented by path coefficients, which indicate the strength of each direct effect on the response variable (Mitchell, 1993; Sokal \& Rohlf, 1995). The variables dry weight of crop residues, dry weed biomass and overall abundances of detritivorous, predaceous and phytophagous arthropods met normality assumptions (PROC UNIVARIATE: SAS Institute, 1991), so transformation was not necessary.

\section{Results \\ Impact on arthropods}

In the first year of the experiment, 32 arthropod species were collected from the bean canopy throughout the cultivation cycle: two detritivores, five parasitoids, 12 herbivores and 13 predators. In the second year, 34 arthropod species were collected: three detritivores, seven parasitoids, ten herbivores and 14 predators. Species diversity for all guilds was similar among the treatments $(P>0.05)$.

Out of the total collected, 12 arthropod species had frequency of capture above $10 \%$ in the two years (table 1). Hypogastrura sp. (Collembola: Hypogastruridae) was the most frequent species amongst detritivores, as was Empoasca kraemeri (Hemiptera: Cicadellidae) amongst herbivores and Cheyletus sp. (Acari: Cheyletidae) amongst predators (table 1). These 12 species were then used for selecting the 
Table 1. Abundance (mean \pm standard error) of arthropods associated with the canopy of common beans grown under no-tillage or conventional cultivation with retention or removal of residues of the previous maize crop. Only arthropods showing frequency of capture above $10 \%$ are listed.

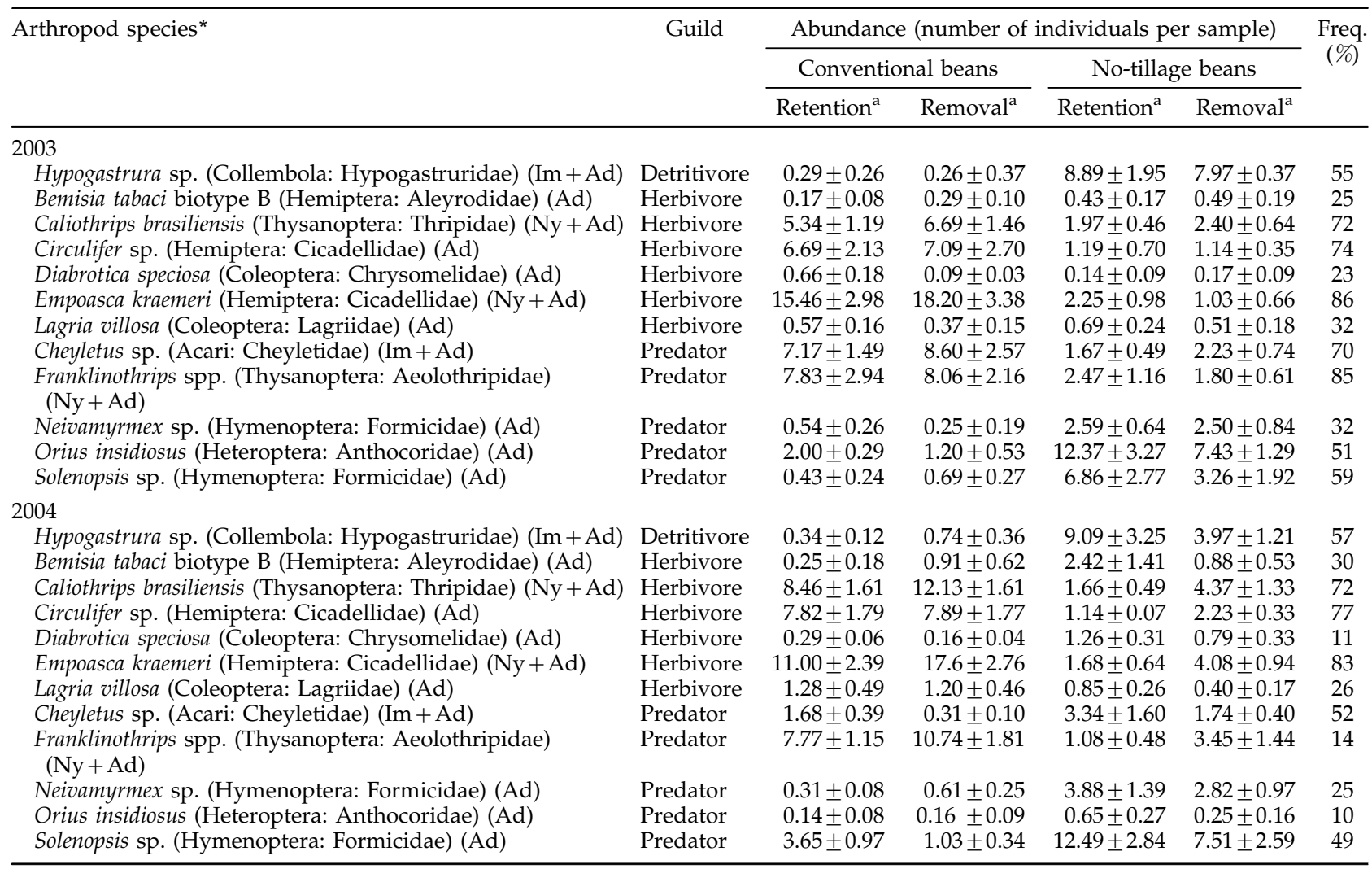

* Im = Immature, Lv = Larva, Ad = Adult, $\mathrm{Ny}=\mathrm{Nymph}$.

a Residue management of the previous maize crop.

Table 2. Step-wise selection summary for the ordination procedure run to select arthropod species to be included in the canonical variate analysis for maximum discrimination among treatments.

\begin{tabular}{|c|c|c|c|c|c|c|}
\hline \multirow[t]{2}{*}{ Step } & \multirow[t]{2}{*}{ Variables } & \multirow[t]{2}{*}{ Partial $R^{2}$} & \multicolumn{2}{|c|}{$F$-test of the covariance analysis } & \multicolumn{2}{|c|}{ Squared partial correlation } \\
\hline & & & $F$-value & $P$ & $\begin{array}{l}\text { Average squared } \\
\text { canonical correlation }\end{array}$ & $P$ \\
\hline \multirow[t]{2}{*}{1} & Hypogastrura sp. & 0.53 & 103.46 & $<0.0001$ & 0.18 & $<0.0001$ \\
\hline & Herbivores & & & & & \\
\hline 6 & Caliothrips brasiliensis & 0.06 & 6.18 & 0.0004 & 0.26 & $<0.0001$ \\
\hline \multirow[t]{2}{*}{3} & Diabrotica speciosa & 0.02 & 2.24 & 0.0836 & 0.23 & \\
\hline & Predators & & & & & \\
\hline 8 & Franklinothrips spp. & 0.10 & 10.41 & $<0.0001$ & 0.30 & $<0.0001$ \\
\hline 4 & Neivamyrmex sp. & 0.04 & 3.91 & 0.0093 & 0.24 & $<0.0001$ \\
\hline 7 & Solenopsis sp. & 0.09 & 8.78 & $<0.0001$ & 0.28 & $<0.0001$ \\
\hline
\end{tabular}

most representative ones using the STEPWISE selection of the STEPDISC procedure of SAS (table 2). One detritivorous species (the collembolan Hypogastrura sp.), four herbivores (the leafhoppers Circulifer sp. and Empoasca kraemeri, the thrips Caliothrips brasiliensis, and the rootworm Diabrotica speciosa) and three predators (the thrips Franklinothrips spp. and the ants Neivamyrmex sp. and Solenopsis sp.) accounted for most of the total variance explained $(30 \%$, as indicated by the squared partial correlation) and were therefore selected for further analysis (table 2).

A Canonical Variate analysis for cultivation system (conventional and no-tillage) and residue management of 
Table 3. Canonical axes and their loadings (between canonical structures) of the effect of residue management of the preceding crop on arthropod assemblages associated with the canopy of common beans under no-tillage and conventional cultivation.

\begin{tabular}{|c|c|c|c|c|}
\hline \multirow[t]{3}{*}{ Variable (arthropod species) } & \multicolumn{4}{|c|}{ Canonical axis } \\
\hline & \multicolumn{2}{|c|}{2003} & \multicolumn{2}{|c|}{2004} \\
\hline & 1 st & 2nd & 1 st & 2nd \\
\hline Detritivore Hypogastrura sp. & -0.46 & -0.20 & -0.37 & -0.28 \\
\hline $\begin{array}{l}\text { Herbivores } \\
\text { Caliothrips brasiliensis } \\
\text { Circulifer sp. } \\
\text { Empoasca kraemeri } \\
\text { Diabrotica speciosa }\end{array}$ & $\begin{array}{r}-0.01 \\
-0.16 \\
-0.25 \\
0.07\end{array}$ & $\begin{array}{l}0.01 \\
0.16 \\
0.24 \\
0.03\end{array}$ & $\begin{array}{r}0.03 \\
-0.69 \\
-0.50 \\
-0.23\end{array}$ & $\begin{array}{r}0.09 \\
0.43 \\
0.09 \\
-0.05\end{array}$ \\
\hline $\begin{array}{l}\text { Predators } \\
\quad \text { Franklinothrips spp. } \\
\quad \text { Neivamyrmex sp. } \\
\quad \text { Solenopsis sp. } \\
F \\
\text { df (num; den) } \\
P \\
\text { Squared canonical correlation }\end{array}$ & $\begin{array}{c}0.14 \\
0.12 \\
0.27 \\
17.57 \\
24 ; 363 \\
<0.001 \\
0.90\end{array}$ & $\begin{array}{c}0.02 \\
-0.03 \\
-0.19 \\
2.28 \\
14 ; 252 \\
0.005 \\
0.06\end{array}$ & $\begin{array}{c}0.11 \\
0.13 \\
0.31 \\
10.71 \\
24 ; 363 \\
<0.001 \\
0.81\end{array}$ & $\begin{array}{c}-0.04 \\
0.15 \\
0.18 \\
4.29 \\
14 ; 252 \\
0.003 \\
0.12\end{array}$ \\
\hline
\end{tabular}

the previous maize crop (retention and removal) indicated significant overall differences among the treatments regarding their species composition and abundance in the first year (Wilks' $\lambda=0.11, F=10.71, \mathrm{df}=24,263, P<0.0001$ ) and second year (Wilks' $\lambda=0.21, F=18.10, \mathrm{df}=30,362, P<0.0001$ ). Four canonical axes were calculated, and two of these were significant $(P<0.0001$ and $P=0.005)$, explaining $90 \%$ and $6 \%$, respectively, of the accumulated variance in the first year (table 3). Likewise in the second year, two axes were significant $(P<0.0001$ and $P=0.0029)$, explaining $81 \%$ and $12 \%$ of the variance. Based on their canonical loadings, the species that most contributed to the divergence among the treatments were Solenopsis sp. (1st axis in the two years), E. kraemeri (2nd axis in the first year) and Circulifer sp. (2nd axis in second year), with opposing contributions of Hypogastrura sp. (1st and 2nd axes in the first year) and Circulifer sp. (1st axis in the second year) (table 3). Therefore, the detritivore Hypogastrura sp., herbivores E. kraemeri, and Circulifer sp., and the predator Solenopsis sp. were the most relevant species explaining treatments differences and were selected for further analysis.

The ordination diagrams derived from the CVA (fig. 1) with the two significant canonical axes show clear distinction between tillage systems in two years and between the types of residue management in the second year. Removal of the maize crop residues (i.e. maize for silage) had no effect on the arthropod assemblage in conventional beans, but significantly affected it in no-tillage beans in the second year (fig. 1), reducing the overall arthropod abundance, especially that of Hypogastrura sp. and Solenopsis sp. and increasing infestation by Circulifer sp. and E. kraemeri (table 1).

The fluctuation of Hypogastrura sp., E. kraemeri, Circulifer sp. and Solenopsis sp. over time is shown in fig. 2. For all these species, the analysis of repeated-measures data indicated significant effect $(P<0.05)$ of cultivation system and residue management of the preceding maize crop over time. The detritivore Hypogastrura sp. and the predator Solenopsis sp. were more abundant in no-tillage beans than in

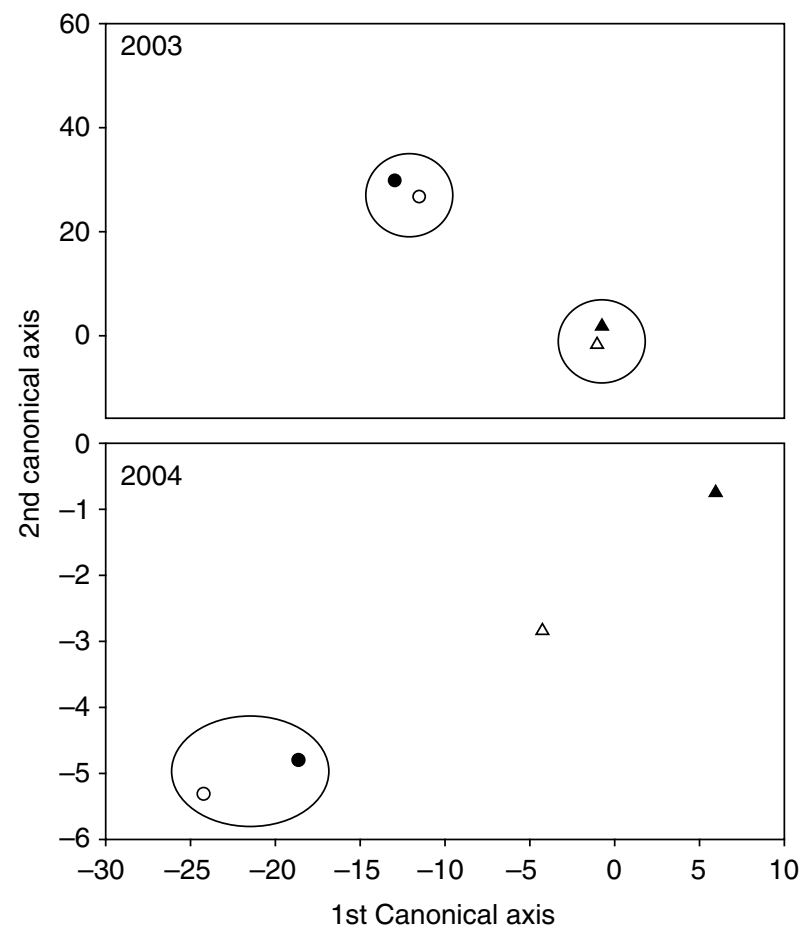

Fig. 1. Ordination (CVA) diagram showing the discrimination of arthropod abundance in fields with conventional (circle) or no-tillage beans (triangle) and with retention (filled symbols) or removal of crop residues of the previous maize planting (open symbols). Symbols are centroid of treatments and represent the class mean canonical variates. Treatments clustered within a large circle are not significantly different by the approximate F-test $(P<0.05)$, based on the Mahalanobis distance between class means (-, conventional tillage, crop residue kept in the field; $\bigcirc$, conventional tillage, crop residue removed; $\boldsymbol{\Delta}$, no-tillage, crop residue kept in the field; $\triangle$, no-tillage, crop residue removed).

conventional beans in the two years (fig. 2a, d). Conversely, the herbivores E. kraemeri and Circulifer sp. were more abundant on beans grown under no-tillage relative to the conventional system (fig. $2 b, c)$.

No-tillage beans grown in plots with maize crop residues had the highest population densities of Hypogastrura sp. and Solenopsis sp., especially in the second year of the experiment (fig. 2a, d). On the other hand, conventional beans grown in plots without maize residues tended to have the highest infestation by E. kraemeri, especially in the second year of the experiment (fig. 2b).

\section{Weed biomass, maize crop residues and yield of beans}

Table 4 shows the results obtained for bean yield, and mass of weeds and maize crop residues. In the first year of the experiment, the highest bean yield was obtained in the combination no-tillage/retention crop residues while the lowest yield was obtained in conventional beans without maize residues. In the second year, however, bean yield was higher under no-tillage relative to conventional tillage regardless of maize residue management. As expected, the 

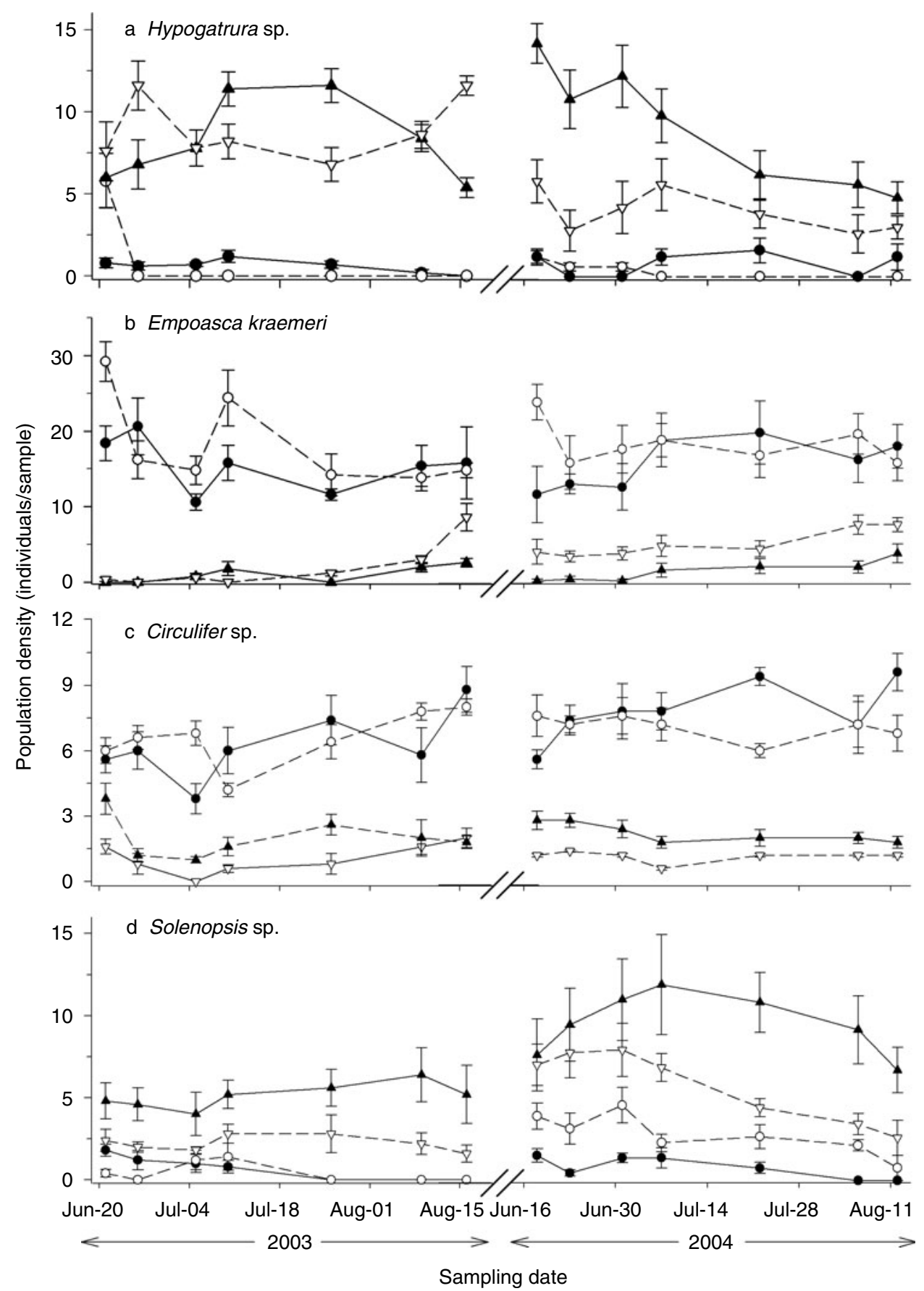

Fig. 2. Fluctuation (mean \pm standard error) of the main (a) detritivorous, $(b, c)$ herbivorous and (d) predaceous species associated with the canopy of bean plants under no-tillage (triangle) or conventional cultivation (circle) when residues of the previous maize crop were kept in the field (filled symbols) or removed (open symbols) (-O-, conventional tillage, crop residue kept in the field; - $\bigcirc-$, conventional tillage, crop residue removed; $-\mathbf{\Delta}-$, no-tillage, crop residue kept in the field; $-\triangle-$, no-tillage, crop residue removed)

weed biomass under conventional tillage was greater than under no-tillage. The weed biomass in plots without maize crop mulching was also greater than in plots with mulching under the conventional tillage, although the same trend was observed under no-tillage as well, especially in the first year.
The amount of organic detritus present in the bean crop with maize mulching was greater than it was without mulching. Also, in plots without mulching, the organic detritus present in no-tillage beans was greater than it was under the conventional cultivation 
Table 4. Effect of tillage and residue management of the previous crop on the yield of dry beans, amount of crop residue and weed biomass present in the bean crop during the growing seasons of 2002 and 2003.

\begin{tabular}{lcrr}
\hline Tillage/Crop residue management & Yield of dry beans (ton ha $\left.{ }^{-1}\right)$ & Crop residue $\left(\mathrm{g} \mathrm{m}^{-2}\right)$ & ${\text { Weed biomass }\left(\mathrm{g} \mathrm{m}^{-2}\right)}$ \\
\hline 2003 & & & \\
No-tillage/retention & $2.83 \pm 0.03 \mathrm{a}$ & $105.36 \pm 3.62 \mathrm{a}$ & $9.98 \pm 1.01 \mathrm{c}$ \\
No-tillage/removal & $2.42 \pm 0.08 \mathrm{ab}$ & $0.80 \pm 0.11 \mathrm{c}$ & $15.67 \pm 1.50 \mathrm{c}$ \\
Conventional/retention & $2.35 \pm 0.17 \mathrm{ab}$ & $0.70 \pm 2.66 \mathrm{~b}$ & $89.95 \pm 3.64 \mathrm{~b}$ \\
Conventional/removal & $2.00 \pm 0.12 \mathrm{~b}$ & & $134.11 \pm 5.20 \mathrm{a}$ \\
& & & \\
No-tillage/retention & $3.25 \pm 0.09 \mathrm{a}$ & $0.60 \pm 0.09 \mathrm{c}$ & $14.50 \pm 0.79 \mathrm{c}$ \\
No-tillage/removal & $2.91 \pm 0.12 \mathrm{a}$ & $24.38 \pm 1.93 \mathrm{~b}$ & $17.91 \pm 0.52 \mathrm{c}$ \\
Conventional/retention & $2.26 \pm 0.18 \mathrm{~b}$ & $83.63 \pm 3.42 \mathrm{~b}$ \\
Conventional/removal & $1.97 \pm 0.18 \mathrm{~b}$ & $0.80 \pm 0.11 \mathrm{c}$ & $147.52 \pm 12.09 \mathrm{a}$ \\
\hline
\end{tabular}

For each year, means \pm standard error followed by the same letter in a column are not significantly different $(P>0.05)$ according to Tukey's honestly significant difference (HSD) procedure.

* Crop residue management of the preceding maize planting.

\section{Relationship between weed biomass, maize crop residues and population density of the main arthropod species}

Figure 3 shows the path diagram for the hypothesized interaction model composed by maize crop residues, weed biomass, Hypogastrura sp., Solenopsis sp., E. kraemeri, and Circulifer sp. No significant deviation between observed and predicted variance-covariance matrices were observed $\left(\chi^{2}=3.13, \mathrm{df}=1, P=0.0769\right)$, indicating that the model is valid. The higher the amount of plant residues left by the maize crop, the lower was the weed biomass in the bean crop $(r=-0.35, P=0.0044)$. While presence of maize crop residues increased the population density of the detritivore Hypogastrura sp. $(r=0.28, P=0.04)$, the weed biomass reduced it $(r=-0.76, P<0.001)$. Population density of Hypogastrura sp. affected positively the population density of the predator Solenopsis sp. $(r=0.57, P<0.001)$, which in turn affected negatively the population density of E. kraemeri $(r=-0.58, P<0.001)$ and Circulifer sp. $(r=-0.85, P<0.001)$. Population density of these two herbivores were significantly correlated $(r=0.86, P<0.001)$.

\section{Discussion}

This research focused on the effects of contrasting soil management practices and the retention or removal of crop residues on the arthropod community of the canopy of $P$. vulgaris, trying to understand processes that have consequences for integrated pest management. Higher abundance of arthropods was observed under no-tillage relative to conventional cultivation and with retention of maize crop residues relative to their removal. This is a likely consequence of variation of resources used by the arthropods in these different systems, especially organic detritus (i.e. crop residues), which was significantly higher under notillage and retention of residues of the previous planting (see table 4). Residues supply food and shelter for several arthropod species and maintain the soil with high water and nutrient content allowing many arthropod species to increase in numbers (Stinner \& House, 1990; Kladivko, 2001).

Despite the higher overall arthropod abundance observed under no-tillage, the cultivation system and residue management had different effects depending on the arthropod guild. Our analyses showed that the main species indicating the impact of the cropping system and residue management of

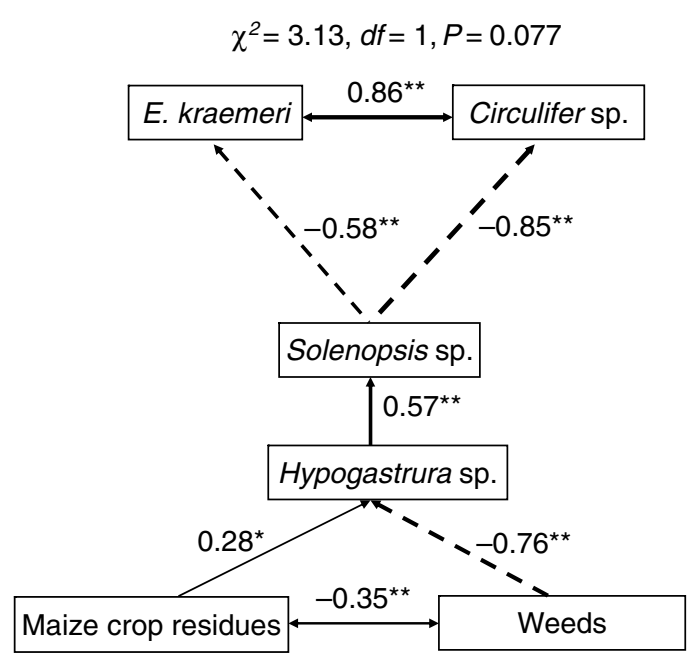

Fig. 3. Path analysis diagram of a model describing direct effects of maize crop residues, weed biomass, Hypogastrura sp., Solenopsis sp., on the infestation of bean plants by E. kraemeri and Circulifer sp. The result of $\chi^{2}$ goodness of fit is indicated and so are path (direct effects) and correlation coefficients for each interaction. One-head arrow indicates causal interaction of one variable on another, and double-headed arrow indicates correlation. Solid lines denote positive effects and dashed lines denote negative effects. The width of each line is proportional to the strength of the relationship, and significant paths $(P<0.05$ or $<0.01)$ are indicated with one or two asterisks, respectively.

the previous crop were the detritivore Hypogastrura sp. (Collembola: Hypogastruridae), the herbivores E. kraemeri and Circulifer sp. (Hemiptera: Cicadellidae) and the predator Solenopsis sp. (Hymenoptera: Formicidae).

Hypogastrura springtails are microarthropods that feed on organic detritus and, together with other Collembola, play an important role in plant litter decomposition processes and in forming soil microstructure (Rusek, 1998). Circulifer and Empoasca leafhoppers are insect-pests of beans that damage plants directly by feeding, causing a characteristic yellowing of tissues, or indirectly as vectors of a variety of plant pathogens (Backus et al., 2005; Munyaneza \& Upton, 2005). Empoasca kraemeri has great economic importance in the 
tropics and subtropics (Abate \& Ampofo, 1996; Murray et al., 2001; Marquini et al., 2002), where it is managed mainly using insecticides, although research is ongoing to develop a better pest management system for these phytosuccivorus insects (Murray et al., 2001; Moura et al., 2007). Solenopsis ants are generalist predators often abundant in tropical ecosystems (Risch \& Carroll, 1982; Way et al., 1998, 2002; Rossi \& Fowler, 2000, 2004).

Infestation levels by leafhoppers were on average sevenfold lower under no-tillage with retention of maize residues relative to conventional tillage with removal of crop residues, whereas the abundance of predatory ants and springtails were, respectively, about seven- and 15-fold higher in that treatment (see table 1, figs 2 and 3). Importantly, during most of the growing season and especially in 2003, the population density of E. kraemeri stayed below or was only slightly above one individual per sample (see fig. 2b), which is considered the economic threshold level based on the sampling methods utilized in the present study (Moura, 2005; Moura et al., 2007). As E. kraemeri is an important pest of beans in the tropics, these results highlight the relevance of using no-tillage and maintaining crop residues so as to reduce the attack of this insect-pest to the crop. Future studies should pursue how leafhopper populations are reduced by tillage and crop residue management.

Under no-tillage, population densities of Hypogastrura springtails and Solenopsis ants were higher than under conventional tillage, and so was their abundance in plots with crop residues, leading to a positive relationship between the amount of residues and the collembolan population (see fig. 3). This is in agreement with other studies showing that elevated organic detritus leads to increases in numbers of detritivorous arthropods (Settle et al., 1996; Rypstra \& Marshall, 2005; Brennan et al., 2006). Because the detritivorous arthropods present in the canopy of bean plants also inhabit the soil, these arthropods also benefit from the favorable soil conditions conferred by zero tillage and elevated levels of crop residues on the soil surface (Stinner \& House, 1990). These conditions should also favor Solenopsis ants by facilitating nest building on the ground and providing low level of mechanical disturbance.

Low population densities of springtails were linked to high weed biomass although we do not know whether this was caused by direct effects of allelochemicals produced by the weed assemblage (Afun et al., 1999; Norris \& Kogan, 2005) or by indirect effects of decreased crop residues associated with high weed biomass (see table 4). Regarding the suppressing effect of the crop residues on the weeds, it is likely that the mulching limited germination of the seed bank by low light penetration and by mechanically preventing emergence (Pullaro et al., 2006).

Intriguing tropic interactions involving organic detritus, detritivores, generalist predators and herbivores was supported by path analysis providing credibility to the hypothesis that soil arthropods (such as Collembola) provide an alternative prey source for generalist predators (such as Solenopsis ants) in the foliage food web which, in turn, initiate a trophic cascade (Settle et al., 1996; Wise et al., 1999; Scheu, 2001). Generalist predators such fire ant species are abundant in a number of tropical agroecosystems (Risch \& Carroll, 1982; Way et al., 1998; Rossi \& Fowler, 2004), and their role in biological control is increasingly being recognized (Rossi \& Fowler, 2000; Stiles \& Jones, 2001; Way et al.,
2002). In addition to the availability of alternative prey, these predaceous ants may have been favored by crop management practices that promoted low levels of soil disturbance and increased habitat complexity (Landis et al., 2000; Symondson et al., 2002; Harvey \& Eubanks, 2004). Future research on their conservation and augmentation, especially through cultural practices and selective use of insecticides (Marquini et al., 2002; Rossi \& Fowler, 2002; Michereff-Filho et al., 2004), will be important to improve their efficiency as biological control agents of bean pests.

The hypothesized trophic interactions in the bean crop involving organic detritus, weeds, springtails, fire ants and leafhoppers deserves further investigation to determine the relative contribution of habitat complexity and availability of alternative prey in promoting biological control and reducing intraguild predation by predatory ants (Way \& Khoo, 1992; Settle et al., 1996; Symondson et al., 2002; Way et al., 2002; Harvey \& Eubanks, 2004, 2005; Rypstra \& Marshall, 2005). Additionally, their feeding choices and amount of prey consumed should be addressed in future studies, perhaps using molecular gut content analyses (Agusti et al., 2003) to determine when and why they switch from feeding on detritivores to feeding on herbivores. Future research should also consider other important trophic interactions involving honeydew-producing insects, such as whiteflies and aphids, which can constitute prey items and also provide considerable amounts of honeydew for Solenopsis species (Helms \& Vinson, 2008).

In summary, this research shows that by using no-tillage and retention of crop residues, infestation levels by insectpests of beans were reduced and population levels of predators and detritivores increased in the canopy of common bean plants. The implications of this study are that cropping systems that include zero tillage and crop residue retention can reduce infestation by foliar insect-pests and increase abundance of predators and detritivores, thus having direct consequences for insect pest management.

\section{Acknowledgements}

We thank the taxonomists J.LM. Carvalho (Instituto Biológico, Campinas), E. Oliveira (INPA, Manaus), A.D. Brescovit (Instituto Butantan, São Paulo), C.G.S. Marinho (UFV, Viçosa) and P.S.F. Ferreira (UFV, Viçosa) for identifying the arthropod specimens collected in this study. The thoughtful comments by two anonymous reviewers and by the subject editor Dr Gordon Port were greatly appreciated. Financial support for this research came from grants and graduate fellowships provided by the following Brazilian agencies: National Council of Scientific and Technological Development (CNPq), Coordination for the Improvement of Higher Education Personnel (CAPES), and the Minas Gerais State Foundation for Research Aid (FAPEMIG).

\section{References}

Abate, T. \& Ampofo, J.K.O. (1996) Insect pests of beans in Africa: their ecology and management. Annual Review of Entomology 41, 45-73.

Afun, J.V.K., Johnson, D.E. \& Russell-Smith, A. (1999) The effects of weed residue management on pests, pest damage, predators and crop yield in upland rice in Cote d'Ivoire. Biological Agriculture \& Horticulture 17, 47-58. 
Agusti, N., Shayler, S.P., Harwood, J.D., Vaughan, I.P., Sunderland, K.D. \& Symondson, W.O.C. (2003) Collembola as alternative prey sustaining spiders in arable ecosystems: prey detection within predators using molecular markers. Molecular Ecology 12, 3467-3475.

Andow, D.A. (1991) Vegetational diversity and arthropod population response. Annual Review of Entomology 36, 561586.

Backus, E.A., Serrano, M.S. \& Ranger, C.M. (2005) Mechanisms of hopperburn: an overview of insect taxonomy, behavior, and physiology. Annual Review of Entomology 50, 125-151.

Badji, C.A., Guedes, R.N.C., Silva, A.A. \& Araujo, R.A. (2004) Impact of deltamethrin on arthropods in maize under conventional and no-tillage cultivation. Crop Protection 23, 1031-1039.

Brennan, A., Fortune, T. \& Bolger, T. (2006) Collembola abundances and assemblage structures in conventionally tilled and conservation tillage arable systems. Pedobiologia 50, 135-145.

Carcamo, H.A., Niemala, J.K. \& Spence, J.R. (1995) Farming and ground beetles - effects of agronomic practice on populations and community structure. Canadian Entomologist 127, 123-140.

Díaz-Zorita, M., Duarte, G.A. \& Grove, J.H. (2002) A review of no-till systems and soil management for sustainable crop production in the subhumid and semiarid Pampas of Argentina. Soil and Tillage Research 65, 1-18.

FAO (2009) Food and Agriculture Organization of United Nations. Available online at http://faostat.fao.org/site/ 339/default.aspx (accessed 13 October 2009).

Fornasieri, C.R.F. (1992) A Cultura do Milho. 310 pp. Jaboticabal, São Paulo, Brazil, FUNEP.

Gebhardt, M.R., Daniel, T.C., Schweizer, E.E. \& Allmaras, R.R. (1985) Conservation Tillage. Science 230, 625-629.

Harvey, C.T. \& Eubanks, M.D. (2004) Effect of habitat complexity on biological control by the red imported fire ant (Hymenoptera: Formicidae) in collards. Biological Control 29, 348-358.

Harvey, C.T. \& Eubanks, M.D. (2005) Intraguild predation of parasitoids by Solenopsis invicta: a non-disruptive interaction. Entomologia Experimentalis et Applicata 114, 127-135.

Helms, K.R. \& Vinson, S.B. (2008) Plant resources and colony growth in an invasive ant: the importance of honeydewproducing Hemiptera in carbohydrate transfer across trophic levels. Environmental Entomology 37, 487-493.

House, G.J. \& Stinner, B.R. (1983) Arthropods in no-tillage soybean agroecosystems: community composition and ecosystem interactions. Environmental Management 7, 23-28.

Kedwards, T.J., Maund, S.J. \& Chapman, P.F. (1999) Community level analysis of ecotoxicological field studies: II. Replicated-design studies. Environmental Toxicology and Chemistry 18, 158-166.

Kladivko, E.J. (2001) Tillage systems and soil ecology. Soil and Tillage Research 61, 61-76.

Landis, D.A., Wratten, S.D. \& Gurr, G.M. (2000) Habitat management to conserve natural enemies of arthropod pests in agriculture. Annual Review of Entomology 45, 175201.

Magalhães, B.P. \& Carvalho, S.M. (1988) Insetos associados à cultura. pp. 573-589 in Zimmermann, M.J.O., Rocha, M. \& Yamada, T. (Eds) Cultura do Feijoeiro: Fatores que Afetam a Produtividade. Piracicaba, Brazil, Potafos.

Marasas, M.E., Sarandon, S.J. \& Cicchino, A.C. (2001) Changes in soil arthropod functional group in a wheat crop under conventional and no-tillage systems in Argentina. Applied Soil Ecology 18, 61-68.

Marquini, F., Guedes, R.N.C., Picanco, M.C. \& Regazzi, A.J. (2002) Response of arthropods associated with the canopy of common beans subjected to imidacloprid spraying. Journal of Applied Entomology 126, 550-556.

Michereff-Filho, M., Guedes, R.N.C., Della-Lucia, T.M.C., Michereff, M.F.F. \& Cruz, I. (2004) Non-target impact of chlorpyrifos on soil arthropods associated with no-tillage cornfields in Brazil. International Journal of Pest Management 50, 91-99.

Mitchell, R.J. (1993) Path analysis: pollination. pp. 211-231 in Scheiner, S.M. \& Gurevitch, J. (Eds) Design and Analysis of Ecological Experiments. New York, USA, Chapman and Hall.

Moura, M.F. (2005) Danos, Sistema de Tomada de Decisão de Controle e Distribuição Espacial de Empoasca kraemeri na Cultura do Feijoeiro. 97 pp. Viçosa, Brazil, Universidade Federal de Viçosa.

Moura, M.F., Picanço, M.C., Guedes, R.N.C., Barros, E.C., Chediak, M. \& Morais, E.G.F. (2007) Conventional sampling plan for the green leafhopper Empoasca kraemeri in common beans. Journal of Applied Entomology 131, 215220.

Munyaneza, J.E. \& Upton, J.E. (2005) Beet leafhopper (Hemiptera: Cicadellidae) settling behavior, survival, and reproduction on selected host plants. Journal of Economic Entomology 98, 1824-1830.

Murray, J.D., Michaels, T.E., Pauls, K.P. \& Schaafsma, A.W. (2001) Determination of traits associated with leafhopper (Empoasca fabae and Empoasca kraemeri) resistance and dissection of leafhopper damage symptoms in the common bean (Phaseolus vulgaris). Annals of Applied Biology 139, 319-327.

Norris, R.F. \& Kogan, M. (2005) Ecology of interactions between weeds and arthropods. Annual Review of Entomology 50, 479-503.

Pullaro, T.C., Marino, P.C., Jackson, D.M., Harrison, H.F. \& Keinath, A.P. (2006) Effects of killed cover crop mulch on weeds, weed seeds, and herbivores. Agriculture, Ecosystems $\mathcal{E}$ Environment 115, 97-104.

Resende, M., Curi, N. \& Santana, D.P. (1988) Pedologia e Fertilidade de Solos: Interações e Aplicações. 84 pp. Brasília, Brazil, MEC.

Risch, S.J. \& Carroll, C.R. (1982) Effect of a keystone predaceous ant, Solenopsis geminata, on arthropods in a tropical agroecosystem. Ecology 63, 1979-1983.

Rossi, M.N. \& Fowler, H.G. (2000) Ant predation of larval Diatraea saccharalis Fab. (Lep., Crambidae) in new sugarcane in Brazil. Journal of Applied Entomology 124, 245-247.

Rossi, M.N. \& Fowler, H.G. (2002) Manipulation of fire ant density, Solenopsis spp., for short-term reduction of Diatraea saccharalis larval densities in Brazil. Scientia Agricola 59, 389-392.

Rossi, M.N. \& Fowler, H.G. (2004) Predaceous ant fauna in new sugarcane fields in the state of São Paulo, Brazil. Brazilian Archives of Biology and Technology 47, 805-811.

Rusek, J. (1998) Biodiversity of Collembola and their functional role in the ecosystem. Biodiversity and Conservation 7, 12071219.

Rypstra, A.L. \& Marshall, S.D. (2005) Augmentation of soil detritus affects the spider community and herbivory in a soybean agroecosystem. Entomologia Experimentalis et Applicata 116, 149-157. 
SAS Institute (2001) SAS user's guide: Statistics, version 8.2. Cary, NC, USA, SAS Institute.

Scheu, S. (2001) Plants and generalist predators as links between the below-ground and above-ground system. Basic and Applied Ecology 2, 3-13.

Settle, W.H., Ariawan, H., Astuti, E.T., Cahyana, W., Hakim, A.L., Hindayana, D., Lestari, A.S. \& Sartanto, P. (1996) Managing tropical rice pests through conservation of generalist natural enemies and alternative prey. Ecology 77, 1975-1988.

Shennan, C. (2008) Biotic interactions, ecological knowledge and agriculture. Philosophical Transactions of the Royal Society, Series B: Biological Sciences 363, 717-739.

Soil Survey Staff (1999) Soil taxonomy: A Basic System of Soil Classification for Making and Interpreting Soil Surveys. Washington, DC, USA, USDA, Natural Resources Conservation Service.

Sokal, R.R. \& Rohlf, F.J. (1995) Biometry: The Principles and Practice of Statistics in Biological Research. New York, USA, Freeman.

Stiles, J.H. \& Jones, R.H. (2001) Top-down control by the red imported fire ant (Solenopsis invicta). American Midland Naturalist 146, 171-185.

Stinner, B.R. \& House, G.J. (1990) Arthropods and other Invertebrates in conservation-tillage agriculture. Annual Review of Entomology 35, 299-318.
Symondson, W.O.C., Sunderland, K.D. \& Greenstone, M.H. (2002) Can generalist predators be effective biocontrol agents? Annual Review of Entomology 47, 561-594.

Tonhasca, A. (1993) Carabid beetle assemblage under diversified agroecosystems. Entomologia Experimentalis et Applicata 68, 279-285.

Vieira, C., Paula Jr, P.T.J. \& Borém, A. (2006) Feijão. 600 pp. Viçosa, Brazil, Universidade Federal de Viçosa.

Von Ende, C.N. (1993) Repeated-measures analysis: growth and other time-dependent measures. pp. 113-137 in Scheiner, S. \& Gurevitch, J. (Eds) Design and Analysis of Ecological Experiments. New York, USA, Chapman and Hall.

Way, M.J. \& Khoo, K.C. (1992) Role of ants in pest management. Annual Review of Entomology 37, 479-503.

Way, M.J., Islam, Z., Heong, K.L. \& Joshi, R.C. (1998) Ants in tropical irrigated rice: distribution and abundance, especially of Solenopsis geminata (Hymenoptera: Formicidae). Bulletin of Entomological Research 88, 467-476.

Way, M.J., Javier, G. \& Heong, K.L. (2002) The role of ants, especially the fire ant, Solenopsis geminata (Hymenoptera: Formicidae), in the biological control of tropical upland rice pests. Bulletin of Entomological Research 92, 431-437.

Wise, D.H., Snyder, W.E., Tuntibunpakul, P. \& Halaj, J. (1999) Spiders in decomposition food webs of agroecosystems: theory and evidence. Journal of Arachnology 27, 363-370. 